Yayın Geliş Tarihi: 13.10.2021

Yayına Kabul Tarihi: 25.11.2021

Online Yayın Tarihi: 31.12.2021

http://dx.doi.org/10.16953/deusosbil.1009194
Dokuz Eylül Üniversitesi Sosyal Bilimler Enstitüsü Dergisi Cilt: 23, Say1: 4, Y11: 2021, Sayfa: 1495-1519

ISSN: 1302-3284 E-ISSN: 1308-0911

Araştırma Makalesi

\title{
MODELLING THE INTEREST RATE ASYMMETRIC PASS-THROUGH IN TURKISH LOAN MARKET: NEW EVIDENCE FROM THRESHOLD COINTEGRATION ANALYSIS
}

\author{
Gülden BÖLÜK* \\ Fatih DEMIR
}

\begin{abstract}
The current study aims to examine the relationship between banks' marginal cost (official policy rate) and retail rates in Turkish banking loan market. We tested asymmetric pass-through by using threshold autoregressive (TAR) and momentum threshold autoregressive (MTAR) and weekly data over the period of 2011:1 to 2021:36. Empirical results reveal that there is incomplete pass-through between policy rate and retail lending rates as vehicle, housing, and commercial loans. Moreover, it's found that while housing and commercial loan rates are rigid downward, vehicle loan rates are rigid upward. The weak and incomplete adjustment indicate that contestability in Turkish banking market has worsened during the last decades. Within this context, positive, and negative asymmetries in transmission process of Turkish banking system imply that impact of central bank decision on macroeconomic variables (such as inflation, growth etc.) is accepted to be weak in Turkey.
\end{abstract} Through

Keywords: Market Power, Turkish Banking, Interest Rate, Asymmetric Pass-

\section{TÜRKIYY KREDİ PIYYSASINDA FAIZ ORANI ASIMETRIK GEÇIŞSINIIN MODELLENMESİ: EŞIKK EŞBÜTÜNLEŞME ANALIZINNDEN YENI KANITLAR}

$\ddot{O} z$

Bu çalışma, bankaların marjinal maliyeti (resmi politika orani) ile perakende oranları arasındaki ilişkiyi Türkiye bankacılık kredi piyasası kapsamında analiz etmeyi amaçlamaktadır. Asimetrik geçişkenliği, eşik otoregresif (TAR) ve momentum eşik

Bu makale için önerilen kaynak gösterimi (APA 6. Sürüm):

Bölük, G., Demir, F. (2021). Modelling the interest rate asymmetric pass-through in Turkish Loan Market: New evidence from threshold cointegration analysis. Dokuz Eylül Üniversitesi Sosyal Bilimler Enstitüsü Dergisi, 23 (4), 1495-1519.

* Doç. Dr., Akdeniz Üniversitesi, İktisadi ve İdari Bilimler Fakültesi, İktisat Bölümü, ORCID: 0000-0001-8901-8503, guldenboluk@akdeniz.edu.tr.

** Dr. Öğr. Üyesi, Süleyman Demirel Üniversitesi, İktisadi ve İdari Bilimler Fakültesi, Ekonometri Bölümü, ORCID: 0000-0002-6787-3960, fatihdemir@sdu.edu.tr. 
otoregresif (MTAR) modellerini ve 2011: 1-2021: 36 dönemi haftallk verileri kullanarak test ettik. Ampirik sonuçlar, politika faiz oranı ile taşıt, konut ve ticari kredilerden oluşan perakende kredi oranlar arasında tamamlanamayan geçişkenlik olduğunu ortaya koymaktadır. Ayrıca konut ve ticari kredi oranlarının aşağ yönlü katı, araç kredisi oranlarının ise yukarı yönlü katı olduğu görülmüşı̈̈r. Zayıf ve tamamlanamayan ayarlama, son on yılda Türk bankacılık piyasasındaki rekabet edilebilirliğin kötüleştiğini göstermektedir. Bu bağlamda, Türk bankacılık sisteminin aktarım sürecindeki pozitif ve negatif asimetriler, Türkiye'de merkez bankası kararlarının makroekonomik değişkenler (enflasyon, büyüme vb.) üzerindeki etkisinin zaylf olarak kabul edildiğini göstermektedir.

Anahtar Kelimeler: Piyasa Gücü, Türk Bankacılı̆̆l, Faiz Oranı, Asimetrik Geçiş

\section{INTRODUCTION}

An essential question in economy is the microeconomic issue of whether prices asymmetrically sticky-whether the speed at which a price increases is different from the speed at which it decreases. An important set of prices in the macroeconomy are consumer "interest rates" (hereafter IRs) determined by banks due to their key role in the monetary policy mechanism (Scholnick, 1999). To implement effective monetary policy, when Central Banks increase or decrease its policy IRs (official rates), retail banks should react by transferring any costs to the commercial banks' lending and deposit rates. A close link between retail interest rate (hereafter $\mathrm{RR}$ ) and policy IR (or money market rate) refer to a high interest-rate pass-through (hereafter IRPT). A higher pass-through (hereafter PT) from official market rate to RRs signals more effectively functioning banking system and effective monetary policy. Commercial banks should transfer any increase or decrease of policy IR to RRs (including the lending and deposit) rates. As mentioned above, this transmission process is called to be "IRPT" (Matemilola et.al., 2015). If IRPT is incomplete this might violate the Taylor principle ${ }^{1}$ and monetary policy aiming to stabilize the economy will be ineffective (Aziakpono and Wilson, 2013). If monetary policy is efficient, an increase or decrease in the central bank official rate is meant to be transferred to RR, finally having effect on consumer and business lending rates, investments, inflation rate and therefore aggregate demand and economic growth (Haughton and Iglesias, 2012; Karagiannis et.al., 2010). There is ongoing controversy over whether this transmission process is symmetric or not (Roelands, 2012). Empirical studies indicated that this transmission process from policy rate (set by central bank) to commercial bank IRs incomplete and may be asymmetric. According to the this, commercial banks tend to raise retail rates on loans at roughly the same speed as the reference rate, but they lower their rates on loans more slowly.

When policy rate was raised by the central bank, commercial banks increase retail lending rates quickly and by roughly the same amount. However, when policy rate falls, bank retail lending rates adjust more sluggishly and not completely. In

\footnotetext{
${ }^{1}$ Taylor principle points out that "central bank should change its interest rate instrument more than one-to-one with increases in inflation and monetary policy would fail to be stabilizing" (Marotta, 2009).
} 
other words, pass-through usually appears to be less complete during falling rate periods compared to rising rate periods. Since asymmetric transmission of bank IR in case of expansionary or contractionary monetary policy might have different effect on price stability as well as the economic growth, understanding how much, how fast, and how symmetrically a decrease or increase in the policy IR is passed to $\mathrm{RR}$ is very important for designing and implementing of monetary policy (Gambacorta and Iannotti, 2007). The nature of asymmetric pass-through (hereafter APT) in banking system is of great importance in two respects: First, since commercial rates affect the output and price level in the economy and second it provides better understanding of commercial banks' conduct and competitive conditions in the retail segment of banking sector (Malile, 2013). Moreover, detecting the APT from benchmark policy rate to RR would give insights into pricing behavior of commercial banks in the money market. In this context, we examine the how effectively the policy IRs are transmitted retail lending rates in banking sector for Turkey.

The power of influence of implemented monetary policy on the macroeconomic variables has long attracted the interest of monetary economists, academicians, and policy makers. There are too many studies on APT issue, however, to date empirical evidence from literature has reached contradictory findings. The literature also reveals different results in the short and long term. APT in interest rate adjustment has also attracted attention in industrial organization literature to clarify how costs are transferred through to prices in oligopolistic market since deposit taking institutions have monopoly power in price setting (Hofmann and Mizen, 2004). If market structure is competitive, "profit-maximizing bank will adjust their rates immediately to changes in the market conditions, but if the market conditions are not perfect (owing, barrier to entry or imperfect competition), bank IRs may be rigid due to inefficiency" (Aziakpono and Wilson, 2013, p.4). In a highly concentrated market, oligopolistic behavior of banks may be a reason of asymmetric adjustment of IR in response to changes (downward or upward) in benchmark policy IR (Aziakpono and Wilson, 2013). As highlighted by Sznajderska (2012), fierce competition among the banks appear to cause quicker IRPT. For example, by evaluating the IRPT in Italy Gambacorta and Iannotti (2007) revealed that when the Consolidated Law, which is amplified the competition, was enforced in Italy in 1993, the speed of IRPT increased and asymmetry related to monetary policy regime almost disappeared. Based on the "structure-conduct-performance (SCP) paradigm " higher market concentration will reduce the competition by facilitating explicit collusion among the firms. Accordingly, Sorensen and Werner (2006) found out that the high degree of concentration negatively affects the speed of IRPT in the euro area. Therefore, it seems that banks tend to set high interest margins (less competitive) on lending and deposit rates in case of high degree of concentration. In the same way, Corvoisier and Gropp (2001), Maudos and de Guevara (2004), Cottarelli and Kourelis (1994) and Borio and Fritz (1995) empirically proved that 
stronger market power (i.e., reduction in a competitive pressure due to entry barriers) leads stickier lending rates in banking industry.

Theoretically, there are different factors can affect the adjustment of IR such as monetary policy orientation, financial structure, bank size, the degree of financial market openness, menu cost, asymmetric information etc. Among the others, monopoly power is one of the reason APT in money market but most common one. Turkish banking sector underwent structural changes after the period of financial liberalization in 1980s (Gunalp and Celik, 2006). Moreover, after 2001 crisis, the macroeconomic conditions led to important restructuring process in Turkish banking sector. This restructuring of banking industry led increase in concentration rates due to mergers and acquisition activities and liquidation of some insolvent banks (Abbasoglu et.al., 2007). Some studies examined the competitive structure of Turkish banking sector (See Repkova and Stavarek, 2014; Contuk and Burucu, 2016) and concluded that "banks in Turkey do not operate in a competitive environment, and they seek and utilize monopoly rents IRT". Moreover, twelve banks were fined for adopting anti-competitive loan policy by Turkish Competition Authority in 2013 in Turkey (TCA, 2013).

Therefore, whether PT is symmetric or not is very important for Turkey that experienced financial reforms in last decades, which can reduce the effectiveness of monetary policy. As a results of implemented financial reforms the number of banks increased, and competition accelerated between commercial banks and other financial institutions in Turkey. However, since banks worked under the small profit margins, merger and acquisition activities involving many banks accelerated to benefit efficiency gains and as a result concentration rate increased. This may have already affected the efficiency of the banking sector and monetary policy to stabilize the economy. Recently, monetary policy has become very important in terms of the stability of the economy since Turkish economy faced with hard times due to currency crisis in August 2018, prolonged high inflation, and Covid-19 pandemia. Although, pass-through process plays very important role in terms of the efficiency of monetary policy in Turkey, research on APT of interest rates in Turkey is comparatively rare. There are few studies (to our best knowledge) focusing on APT in Turkey and findings of these studies are controversial (see Aydın (2007), Özdemir (2009), Yüksel and Özcan (2015) and Yıldırım (2014), Binici et.al. (2018), Avci and Yucel (2017) Sahin and Cicek (2018)). While Ozdemir (2009), Yüksel and Özcan (2015), and Avci and Yucel (2017) rejects the asymmetry in IRPT, others found some evidence supporting the APT hypothesis in Turkish money market.

The main contribution to previous studies is two folds: First, the time interval of our dataset is based on the longer period ranges 2011 to 2020 and contains more recent observations, which covers the unconventional monetary policy period of the Central Bank of Republic of Turkey (CBRT) that implements a wide asymmetric IR corridor as a policy tool. Secondly, apart from the previous studies on Turkey, we use weekly data since a weekly approach will produce more accurate trend and better 
reflects shifts in RRs. For this purpose, in this study, how policy rate changes are passed to retail lending rates has been examined for Turkey. In order to determine the APT between IRs, threshold cointegration test based on TAR and M-TAR proposed by Enders and Siklos (2001) has been employed for empirical analysis.

The rest of this paper is organized as follows. Section 2 presents brief information on the structure of Turkish banking industry. Section 3 gives a review on the literature related to the asymmetric interest pass-through in banking sector. Section 4 describes the data and methodological approach adopted, while Section 5 presents and interprets the empirical findings. Finally, Section 6 concludes.

\section{BRIEF INFORMATION ON THE STRUCTURE OF TURKISH BANKING SECTOR}

Turkish banking sector experienced important structural changes after the financial liberalization program in January 1980. By this program it was targeted to increase efficiency and competitiveness of banking sector in Turkey. With the implementation of liberalization program, the number of banks increased from 43 in 1980 to 79 in 2000 as a result of abolishment of many restrictions on market entry, IRs and exchange rates. The number of foreign and national banks, their branches, total assets and shares in GNP increased between 1980-2000. Although the share of publicly owned banks decreased from 44 to 34 in this period, they were dominant position in banking sector. Despite the number of foreign banks increased, their share in the sector remained small. The profitably of Turkish banking sector also increased. For example, real profits of private banks increased five-fold during 19811990 period. However, some studies (See Zaim (1995), Mercan and Yolalan (2000) and Kasman (2002)) highlighted that in spite of the efficiency gains in 1980s, high profit rates were realized due to monopoly power not the efficiency gains after 1994 . Günalp ve Çelik (2006) analyzed the degree of competition in Turkish banking market by using S-C-P paradigm and efficiency hypothesis and found that banks earned high revenue since they operate under imperfect competition. Moreover, authors concluded that liberalization process and deregulation program in 1980 induced the competition among the banks in the sector. After 2001 crisis macroeconomic development led to important structural change in Turkish banking sector due to merger and acquisition operations and liquidation of some insolvent banks. Abbasoglu et.al. (2007) by using Panzar and Rosse's approach and data from 2001-2005 evaluated the level of concentration and competition in Turkish banking sector. Although authors found no link between concentration level and competition, they concluded that concentration ratio increased in analyzing period due to increasing trend of HHI. Moreover, the structure of banking market in Turkey was found to be monopolistic competition instead of oligopoly (Abbasoğlu et.al., 2007).

Turkish banking sector (like in many industrialized and emerging countries) has experienced structural changes because of implemented structural reforms and liberalization program in the last decades. The main purpose of these efforts was to set up more competitive and efficient banking sector. However, since the 
liberalization program was implemented without the macroeconomic stability, reform efforts ended up with serious crises in 1994 and 2001. Many banks went bankrupt, and all their assets were transferred to the Saving Deposit Insurance Fund. In the context of standby agreement with the International Money Fund (IMF), government put into force a new financial restructuring program highlighting the "importance of governmental regulation and supervision to enhance the soundness and stability of the banking system". Moreover, a new regulatory authority, named as Banking Regulation and Supervision of Turkey was established. Since efficiency was important to survive, a consolidation wave became inevitable through merger and acquisition operations. Moreover, the share of foreign ownership in Turkish banking sector increased in this period (Kasman and Kasman, 2015).

Turkish banking system has three ownership types: state owned banks, foreign owned banks and domestically owned private banks. Following the 2001 financial crisis, many banks were forced to exit the banking system. After the Turkish Banking Restructuring Program in 2001, the structure of banking market substantially changed; the number of banks decreased, and relative share of banks also differentiated. Furthermore, many banks left the Turkish banking sector in this period. While the total number of banks was 61 before the 2001 crisis, today 49 banks are operating in banking sector (TBB, 2021). Due to structural measures and regulatory reforms, it can be said that Turkish banking market has more robust structure today. Turkish banking has a market dynamic like an emerging market economy. The banking sector has increased its weight in Turkish financial system. Banks still play dominant role since total assets of banking sector was around $87 \%$ of total assets of financial. The ratio of asset size of Turkish banking sector to GDP increased from 0.87 in 2010 to 1.05 in 2019 (TBB, 2021). Therefore, this show that banks have key role in achieving financial stability in the economy.

As highlighted above, the market structure and competitive conditions changed due to liberalization and restructuring process in last decades in Turkey. For example, total number of banks in the sector decreased from 67 in 2001 to 48 in 2020 (- $40 \%$ ) while the total number of branches increased from 6,983 in 2001 to 9,864 (41\%). Total assets have increased by $36 \%$ in 2019 compared to previous year. In this context, Aksoy (2019) evaluated the Turkish banking sector by using Herfhindahl Hieschman and Hall-Tideman indexes and revealed that level of concentration increased in terms of total assets and total deposits in 2003-2016 period. According to the TBB (2021), concentration rate increased from $58 \%$ in 2002 (first five largest banks according to the total asset) to $59 \%$ in 2020 (TBB, 2021). Since Avci and Yucel (2017) found positive relationship between banking industry concentration and IRPT in Turkey, bank RR rates may be asymmetric to actions of central bank. 


\section{LITERATURE REVIEW}

This section presents the theoretical approaches that explaining the phenomenon of APT and then summarizes the results of the empirical studies on APT.

\section{Theoretical Framework}

IRPT defines how changes in authority policy IR are transmitted to bank RRs such as deposit rates and lending rates (Zhang et.al., 2017). Efficient market requires symmetry in pass-through mechanism in IR adjustment. To have an idea about this, by using "symmetry hypothesis" it is tested magnitude of negative and positive adjustment of retail rates (deposit and lending) in reaction to changes in benchmark policy IRs (Karagiannis et.al., 2010). As underlined in the literature banks has a vital role in the IRPT and a fuller and faster PT enhances the effectiveness of monetary policy to ensure stabilized economy (Zhang et.al., 2017).

For the effectiveness of monetary policy, the reaction of RRs to monetary easing and tightening is expected to be symmetric. Moreover, a change in the official IR is passed to other RRs immediately, "while the magnitude of the changes that is passed on to RRs should be large enough to influence aggregate demand" (Apergis and Cooray, 2015, p. 155-156). APT adjustments have important welfare results and policy implications. If IRs adjust upward faster than downward, "commercial banks are in position to generate large profits at the expense of their customers" (Apergis and Cooray, 2015, p.156). Consequently, APT would suggest that customers are not benefiting from any RR reduction. In a symmetric condition when the cost of money (deposits rates) changes, this change should be completely and fully transmitted in short-term RR, which will later be passed on to lending (or long-term) bank rates. $\mathrm{RR}$, however, might be sticky due to factors such as price leadership, imperfect information, menu costs, transaction costs, imperfect competition, central bank intervention etc. (Apergis and Cooray (2015).

Asymmetric behavior of commercial banks is generally explained using two competing hypothesis- "bank's price hypothesis" or "the bank concentration" and "consumer reaction hypothesis". According to the collusive behavior hypothesis ", deposit rates will be rigid upward when the benchmark policy rate of central bank is raised, while the lending rates will be rigid downward when the official rate is increased (Aziakpano and Wilson, 2013). Consumer reaction hypothesis argue that, when retail banks operate in a competitive market condition, they would refrain from the negative reactions of consumers due to lending rate increases or deposit rate decreases. In case of asymmetric adjustment conditions, lending rates would be rigid upwards and deposit rates would be rigid downwards (Jamilov and Egert 2014). However, bank's collusive price hypothesis argue that retail banks are more likely to decrease deposit rates and increase lending rates, in case of banks able to abuse monopoly power and arrange IRs based on their interests (Kargianniset.al., 2010, pp.3-5). The collusive behavior hypothesis focuses on the level of competition 
among commercial banks and the concentration rates of retail market. Under the bank concentration (or collusive price) hypothesis, banks are not willing to decrease lending rates because they hesitate to disrupt their collusive agreements. Therefore, collusive behavior hypothesis claims that lending rates are rigid downwards and the deposit rates upwards (Matemilola et.al., 2015). Hannan and Berger (1991) and Neumark and Sharpe (1992) for example, found evidence that rigidity of RR in US deposit market is greater in highly (more) concentrated regional markets. Similarly, Borenstein et.al. (1997) argue that downward stickiness on the PT of marginal cost to pricing can also be rationalized by a less competitive behavior. Similarly, Neumark and Sharpe (1992) showed that partial reason for asymmetry in bank deposit market is high level of concentration. These findings mean that commercial banks with monopoly power increase deposit rates slowly, but decrease the rates quickly (Jamilov and Egert, 2014).

On the other hand, consumer reaction hypothesis focuses on the reaction of customers to official rate changes. This hypothesis argues that if commercial banks operate competitive conditions, they can not rise the "lending rate because they fear negative reactions from customers". Under this hypothesis, lending rates will be rigid upward when official rate has been increased by central banks (Matemilola et.al, 2015). Other related theories that explain APR are "consumer behavior hypothesis" and "adverse selection hypothesis". The consumer behavior hypothesis underlines the degree of consumer sophistication related to the financial markets. Moreover, search and switching cost related to alternative sources of financing poses the main reasons of this hypothesis. If the rate of unsophisticated consumers higher to rate of sophisticated ones along with the search and switching costs lead banks have stronger market power to IRs to their advantage. Similar to collusive behavior hypothesis, the consumer behavior hypothesis states that lending rates are rigid downward. As pointed out by Stigliz and Weiss (1981), the adverse selection hypothesis argues that asymmetric information causes an adverse selection problem because high IRs attract riskier borrowers. As a result, "banks avoid rises in lending rates and ration credit to circumvent loan default by riskier borrowers" (Matemiola et.al., 2015). In the same way, the adverse selection hypothesis states that lending rates will be rigid upwards like the consumer reaction hypothesis (Matemilola et.al, 2015).

\section{Empirical Evidence}

APT in interest rate in money market is well documented by many empirical studies. For example, employing disaggregated general-to specific (GETS) method Karagiannis et.al. (2010) analyzed the IRPT in Greece, Bulgaria and found evidence supporting negative asymmetry in adjustment of RR for Bulgaria and Slovenia due to different level of competition and liberalization process in these countries. Jamilov and Egert (2014) analyzed the IRPT for Armenia, Azerbaijan, Georgia, Kazakhstan, and Russia (Causes economies) by using ARDL and monthly data. Authors found that IRPT is systematically incomplete and sluggish due to instability in 
macroeconomy and uncompetitive structure of banking sector. Hofmann and Mizen (2004) examined the PT of official rates to individual financial institutions' RR by using monthly data over the period 1985-2001 and cointegration (VAR) method for UK. Authors found complete PT for deposit rates but not for mortgage rates. Haughton and Iglesias (2012), analyzed the impact of IR volatility on RRs and the monetary transmission mechanisms in the countries of Carabian Single Market and Economy using monthly data over the period 1995-2010 and Asymmetric TAR and MTAR cointegration models. Authors found complete PT in retail lending for US, Trinidad and Tobago and St.Lucia but not for other 9 Asian countries. Moreover, they indicated that deposit rate is characterized by upward rigidity due to collusive pricing arrangements. Therefore, commercial banking market in Carabian countries found to be having oligopolistic structure. Gambacorta and Iannotti (2007) examined the velocity and APT of the reaction of bank RRs to monetary policy shocks by using Asymmetric Vector Error Correction Model (AVECM) over the period of 19852002 found evidence supporting APT in Italy in short-run. This result indicated that commercial banks adjust their loans (deposit) rate quickly during the period of monetary tightening (easing). Using quarterly data over the period of 1983-2002 and error correction method (ECM), Chong et.al. (2006) detected APT in benchmark money market and found that adjustment speed of RRs in response to changes in official rates differs across both financial institutions and financial products and tends to be asymmetric. Similarly, using non-linear threshold error correction model and monthly data over 1995-2008 Becker et.al. (2012) validated the APT in UK. Focusing on the 23 banks in the mortgage-lending market in Switzerland, Cecchin (2011) found that the PT of adjustable-rate mortgage is incomplete and sluggish compared to fixed rates, in other words banks react more quickly on impact to falling benchmark rates compared to the opposite case. Moreover, changes in RR found to be transmitted fully and quickly when benchmark rates are decreasing. Author also found that adjustment of fixed-rate mortgage rates displays downward rigidity, which points out the existence of imperfect competition. Cecchin (2011) also revealed that "financial institutions were more prone to passing on market rate changes when rates of fixed-rate mortgages were below their equilibrium, indicating that commercial banks were abusing some degree of monopoly power (collusivepricing hypothesis)". Aziakpono and Wilson (2013) focused on South Africa and demonstrated that commercial banks are not eager to adjust their RRs upward in reaction to policy rate changes due to collusive behavior of banks. Similarly, Lim (2002) analyzed the adjustment process among a bank bill rate, loan rates and deposit rates by using data over the period of 1990-2000 and multivariate ECM in Australian banking sector. Author found that the magnitudes of the short-run response of the loan and deposit rates to shocks are asymmetric between the periods of monetary easing and monetary tightening. In this period, it is seen that banks value their borrowings customers and tend transmit on decreases in the loan rates quicker than they transmit on increases. Author concluded that this strong rigidity comes from the oligopsonic behavior. Using data during the period 1994-2001 and structural ECM model, Liu et.al. (2008) found evidence supporting the APT in the adjustment of RR 
in banking sector in New Zealand. Malile (2013) investigated the APT using the data over the period of 2001-2013 and OLS method for Albenia. Results validated the APT in this country.

Matemilola et.al. (2015) analyzed the IPT using Asymmetric Error Correction Model (AECM) and monthly data over the period 1978-2012 in South Africa and revealed that "commercial banks adjust their lending rate downward but the lending rate rigid upward" (Matemilola et.al., 2015). Another finding is that this rigidity validates the consumer reaction hypothesis in money market. Marotta (2009) examined the role of size and speed of IRPT by using data over the period 19932003 in EU. Author found evidence in favor of APT for France and Netherland. Payne (2007) analyzed the reaction of mortgage IRs to changes in the federal funds rate by using MTAR model and data over the period of 1971-2005 in USA and found evidence in favor of APT in short-run. Payne (2007) analyzed the reaction of adjustable-rate mortgages to federal funds by using MTAR model and the data over the period 1987-2005 in USA. Author results confirmed APT with upward rigidity due to customer reaction and adverse selection hypothesis. Using AECM, Rocha (2012) confirmed significant APT in Portugal over the 1993-2002 period. Sander and Kleimer (2004a) analyzed the IRPT in Euro-zone and found rigidity in shortrun. Another important finding is heterogeneity across the Euro-zone has decreased in some banking markets and higher level of competition improves the PT in deposit markets. Scholnick (1996) detected the APT in Singapore and Malaysia and revealed that deposit rates in both countries are rigid when they are below their equilibrium level (downward rigidity) due to validation of collusion hypothesis. Using threshold error-correction model (TECM), Su and Chang (2010) confirmed the APT in RR for eight Eastern European Countries. Winker (1999) examined the IPT for Germany in 1975-1989 period and found that loan rates react even slower than deposit rates due to asymmetric information. Wang and Thi (2008) analyzed IPT in retail rates in Taiwan and found upward rigidity in deposit rates and downward rigidity in lending rate due to collusive pricing arrangements. Similarly, using EC-EGARCH $(1,1)$ model and monthly date from 1997 to 2004, Wang and Lee (2009) examined the impact of IR volatility on RRs of U.S. and nine Asian countries. Authors results validated the APT due to collusive pricing agreements in five countries. By using threshold asymmetric ECM and monthly data from 1989 to 2011, Valadkhani and Anwar (2012) showed that increases in RRs are transmitted onto the consumer than cuts in Austria. Sznajderska (2012) tested the APT by employing TECM and MTAR models for Poland in 2004-2011 period and revealed that deposit of firms reacts significantly stronger to decreases than to increases of money market rate. Apergis and Cooray (2015) tested IPT in USA, UK and Australian banking sector by using Non-linear Auto-Regressive Distrubuted Lag Model (NARDL) and Error Correction Model (ECM) and found evidence supporting APT in Australia in 2000-2013 period. By using ARDL bounds test and monthly data in 2008-2017 period, Rutayisire (2020) analyzed the transmission process between policy-controlled IRs (repo and treasury bill rates) and the bank deposit rates in Ruwanda and found that IRPT is 
incomplete in banking sector. Similarly, Bennouna (2019) examined the relationship between marginal cost and retail lending rates using quarterly survey data over the 2006-2016 period and panel cointegration method. Her results supported high level asymmetric adjustment over the bank products.

Unlike the studies that found asymmetry in IRPT, some other studies supported the symmetry hypothesis. For example, Sander and Kleimer (2004b) analyzed the transmission of monetary policy onto RRs in banking sector in eight Central and European countries (CEECs). Using the monthly data over the period 1993-2003 and cointegration (VAR) method, authors found homogenous passthrough in CEECs. Scholnick (1999) analyzed whether IRPT is asymmetric or not in Canada and US and found no significant asymmetry in both countries. Yuksel and Ozcan (2015) examined the APT by using TAR and M-TAR models in 2001-2011 for Turkey and found all loan types exhibit symmetric adjustment.

A different group of studies, however, focused on the causes of APT in financial markets. In this context, Quoc and Huy (2013) analyzed the explanatory factors of asymmetric relationship in IRPT by using quarterly data of six commercial banks over the period of 2009-2012 and dynamic model in Vietnam. Authors revealed that capital and liquidity requirements of commercial banks are the main reasons of APT in Vietnam banking sector. Employing Boone indicator for novel measure of competition and ECM van Leuvensteijn et.al. (2007) examined the impact level of competition in loan market on IRs during the period 1994-2004 at regional level in Euro. Authors found that higher level of competition implies significantly lowers spreads between bank and market IRS for most loan market products. Another important finding is that higher level of competition is closely linked with the lower bank RR and stronger PT in IRs. Employing the data of 98 largest bank in US money market, Roelands (2012) demonstrated that the asymmetry in IRPT can be explained by capital and liquidity requirements. Author argued that when banks are constrained, the PT to RR is either incomplete or zero.

\section{DATA AND ECONOMETRIC METHODOLOGY}

\section{Data}

As of the end of 2010, the CBRT preferred a monetary policy in which multiple interest rates were used as a policy tool. This path has created difficulties in understanding exactly what the monetary policy stance is. Therefore, the monetary policy stance of the CBRT has been tried to be followed over an average of the interest rates of different policy instruments at different maturities in which it funds the market. With this approach, the weighted average interest rate is calculated by taking into account the CBRT's overnight lending rate and weekly repo rate, as well as the amount of funding liquidity. This average interest rate, called the weighted average funding cost (WFC), is considered an important indicator of the monetary policy stance (Ekinci et. 2016; Kuzu, 2017). Kara (2015) and Binici et al. (2016) state that monetary policy can be summarized in terms of two interest rates (BIST 
interbank overnight interest rate and average funding rate). In addition, it is emphasized that both interest rates play an important role in determining bank loans and deposit interest rates (Kara, 2015; Binici et al. 2016). However, in a recent study, it was determined that WFC has a greater effect on the bank loan and deposit rates than the BIST interbank overnight interest rate (Büberkökü and Kızılder, 2019). Therefore, WFC has been taken into account as the policy interest rate in the study, with the thought that it represents the monetary policy stance of the CBRT well and has a greater effect on bank loan interest rates.

RRs include weighted average lending rates (cash, vehicle, housing and commercial) in terms of Turkish Lira. All variables consist of 557-week data covering 2011:1-2021:36 period. The data is obtained from the CBRT Electronic Data Delivery System. Descriptive statistics of variables are presented in Table 1.

Table 1: Descriptive Statistics

\begin{tabular}{|l|c|c|c|c|c|}
\hline & Policy Rate & \multicolumn{4}{|c|}{ Retail (Loan) Rate (RR) } \\
\hline & WFC & Cash & Vehicle & Housing & Commercial \\
\hline Mean & 11.09 & 18.25 & 15.88 & 13.58 & 15.63 \\
\hline Maximum & 25.50 & 39.36 & 33.85 & 29.28 & 36.17 \\
\hline Minimum & 4.52 & 8.27 & 9.48 & 8.29 & 8.09 \\
\hline Std. Dev. & 5.37 & 5.12 & 5.07 & 3.97 & 5.09 \\
\hline Observations & 557 & 557 & 557 & 557 & 557 \\
\hline
\end{tabular}

Mean values show that the housing loan IR is close to the policy IR. It can be said that the IR of cash loan is the highest IR. In addition, the highest standard deviation is observed in policy IRs. This indicates that the cost of funding varies more than the loan IRs.

\section{Methodology}

The main aim of the current study is to examine the PT of changes in the policy IR determined by the monetary policy authority to market loan IRs. For this purpose, long and short-run relationships between variables must be determined. However, if the variables are non-stationary, the spurious regression relationship between variables is encountered, as revealed in the studies of Granger and Newbold (1974) and Phillips (1986). Therefore, it is important to determine whether the variables are stationary or not. Stationarity examination can be performed using Augmented Dickey-Fuller (ADF) developed by Dickey and Fuller (1979) and Phillips and Perron (1988) (PP) unit root tests and the order of integration of variables can be revealed. If the variables are integrated of the same order, Engle and Granger (1987) proposed cointegration test based on the motivation that variables may be in a long-run equilibrium relationship. 
According to this approach, Equation (1) is estimated by the Ordinary Least Squares (OLS) method as the first step.

$$
R R_{t}=\theta+\varphi W F C_{t}+\varepsilon_{t}
$$

where $R R$ and $W F C$ denote retail interest rate (loan rates) and policy IR respectively and are integrated of the same order, particularly I(1). In addition, Equation (1) can include trend and lagged dependent variables.

In the second step, residuals $\left(\varepsilon_{t}\right)$ are obtained from Equation (1). If the residuals are stationary at level, it is decided that there is a cointegration relationship between variables. Unit root test based on the ADF procedure shown in equation (2) is applied to residuals. The critical values for unit root test were proposed by MacKinnon (1991).

$$
\Delta \varepsilon_{t}=\vartheta \varepsilon_{t-1}+e_{t}
$$

According to Equation (2), null hypothesis $(\vartheta=0)$ is defined as the presence of a unit root and means that there is no cointegration relationship between variables. The rejection of the null hypothesis is determined that residuals are $\mathrm{I}(0)$ and hence there is a cointegration relationship between variables. Cointegration relationship means that there is a long-run equilibrium relationship between variables. However, deviations from equilibrium can occur in the short-run and a return to long-run equilibrium is provided through the error correction mechanism.

Engle and Granger (1987) is an approach to adjusting symmetrically the effect of shocks that cause short-run deviations. In some cases, however, it can be seen that the deviations that occur in the short-run due to the effects of shocks are adjusted asymmetrically. Although the asymmetric adjustment is valid, a specification error is made if the Engle and Granger (1987) approach is used.

Enders and Granger (1998) and Enders and Siklos (2001) based on the Threshold Autoregressive Model (TAR Model) have come to the fore. In this respect, Enders and Granger (1998) and Enders and Siklos (2001) proposed an approach based on the Threshold Autoregressive (TAR) Model for cointegration relationship between variables integrated of order one.

According to Enders and Siklos (2001), if the shocks in the short-run is asymmetrically adjusted return to long-run equilibrium, threshold cointegration test based on TAR is performed as in Equation (3) taking into account the residuals $\left(\varepsilon_{t}\right)$.

In addition, as shown in Equation (4), threshold cointegration can be expanded by adding lagged of $\Delta \varepsilon_{t}$ to the test equation so that $e_{t}$ could be white noise.

$$
\Delta \varepsilon_{t}=I_{t} \rho_{1} \varepsilon_{t-1}+\left(1-I_{t}\right) \rho_{2} \varepsilon_{t-1}+e_{t}
$$




$$
\Delta \varepsilon_{t}=I_{t} \rho_{1} \varepsilon_{t-1}+\left(1-I_{t}\right) \rho_{2} \varepsilon_{t-1}+\sum_{i=1}^{p-1} \psi_{i} \Delta \varepsilon_{t-i}+e_{t}
$$

where $I_{t}$ is the Heaviside indicator function and is determined as follows:

$$
I_{t}= \begin{cases}1 & \text { if } \varepsilon_{t-1} \geq \tau \\ 0 & \text { if } \varepsilon_{t-1}<\tau\end{cases}
$$

where $\tau$ is the threshold value. For any value of $\tau, \varepsilon_{t}$ is stationary if $\rho_{1}<0$, $\rho_{2}<0$ and $\left(1+\rho_{1}\right)\left(1+\rho_{2}\right)<1$ conditions are valid for Equation (3). The null hypothesis indicating that there is no long-run equilibrium relationship between variables ( $\varepsilon_{t}$ is not stationary at level) is tested as $\rho_{1}=\rho_{2}=0$ in the threshold cointegration test. Moreover, the validity of $\rho_{1}=\rho_{2}$ points to symmetric adjustment, as in Engle and Granger (1987) approach.

A different alternative for $I_{t}$ in Equation (5) is proposed by Enders and Granger (1998). This alternative Heaviside indicator function defined as in Equation (6).

$$
M_{t}= \begin{cases}1 & \text { if } \Delta \varepsilon_{t-1} \geq \tau \\ 0 & \text { if } \Delta \varepsilon_{t-1}<\tau\end{cases}
$$

The use of the $M_{t}$ indicator function on Equation (3) is called Momentum Threshold Autoregressive Model (M-TAR) and defined as Equation (7). Lagged of $\Delta \varepsilon_{t}$ could be added to Equation 7 so that the residuals $\left(e_{t}\right)$ are white noise.

$$
\Delta \varepsilon_{t}=M_{t} \rho_{1} \varepsilon_{t-1}+\left(1-M_{t}\right) \rho_{2} \varepsilon_{t-1}+e_{t}
$$

In the M-TAR Model, as in the TAR Model, the threshold cointegration test is based on testing the null hypothesis $\left(\rho_{1}=\rho_{2}=0\right)$, which means that there is no cointegration. In addition, testing of the null hypothesis $\left(\rho_{1}=\rho_{2}\right)$ defining the symmetric adjustment is also performed.

Akaike (AIC) and Schwarz Information Criteria (SIC) could be used to decide which of the TAR and M-TAR models will be preferred. Critical values for threshold cointegration test were presented in Enders and Siklos (2001). The critical values for the symmetric adjustment test are made through the standard $F$ distribution.

An important issue for TAR and M-TAR Models is the determination of the threshold value $(\tau)$. There are two cases for determining the threshold value; i) given as $\tau=0$ and ii) $\tau$ is unknown. Chan's (1993) proposal may be taken into account for the unknown situation of $\tau$. Chan (1993) suggested that the residuals should be sorted increasingly, removing the smallest and largest $15 \%$ parts and taking all of the residual values as potential threshold values. Afterwards, the model is estimated over each potential threshold value and the threshold value which gives the minimum sum squared residual is selected. 
In the threshold cointegration test equation, $\rho_{1}$ is a positive deviation indicating the situation in which the policy IR of the CBRT decreases or the retail interest rate increases. Furthermore, $\rho_{2}$ is a negative deviation indicating the situation in which the WFC interest rate increases or the RR decreases.

In addition, if $\left|\rho_{1}\right|>\left|\rho_{2}\right|$ is valid, it indicates that decreases in WFC are adjusted faster than increases and is defined as negative asymmetry. However, if there is a situation in the form of $\left|\rho_{2}\right|>\left|\rho_{1}\right|$, it indicates that the increases in WFC are adjusted faster than the decreases and it is defined as positive asymmetry. The common view in the literature is that the positive asymmetry is due to the oligopoly market structure. Also, positive asymmetry is considered against consumers.

If there is a long-run equilibrium relationship and asymmetric adjustment between variables as a result of the threshold cointegration test, short-run relationships are also examined by estimating the threshold error correction model. According to Enders and Siklos (2001), the threshold error correction model is presented in Equation (8) for the TAR Model. And the threshold error correction model for the M-TAR Model is adapted using $M_{t}$ instead of the $I_{t}$ indicator function.

$$
\begin{gathered}
\Delta \mathrm{RR}_{t}=\mu+I_{t} \delta_{1} \varepsilon_{t-1}+\left(1-I_{t}\right) \delta_{2} \varepsilon_{t-1}+\sum_{i=1}^{p} \alpha_{i} \Delta \mathrm{RR}_{t-i} \\
+\sum_{j=1}^{k} \beta_{j} \Delta W F C_{t-j}+v
\end{gathered}
$$

The threshold error correction model presents Granger causality findings as well as determining short-run relationships. In Equation (8), a test can be made by testing the null hypothesis in the form of $\beta_{j}=0$, which states that there is no Granger causality from WFC to RR. The result to be reached by rejecting the null hypothesis is WFC is the Granger cause of RR. In addition, the threshold error correction model enables to determine whether there is an asymmetric adjustment in the short-run. In the test to be made for this, the equality of $\delta_{1}$ and $\delta_{2}$ coefficients in Equation (8) indicates that symmetrical adjustment is valid in the short run.

\section{EMPIRICAL RESULTS}

Before the cointegration test is executed for the variables, there must be determined order of integration of the variables. Therefore, unit root test is employed to find out order of integration firstly. In this step ADF and PP unit root tests are performed to each variable. The null hypothesis of the test is that the series are a unit root, namely non-stationary, against alternative hypothesis of stationary. Besides to determine the threshold cointegration relationship of the series, both must be firstorder integration. 
Unit root test results at levels of the series are shown Panel A in Table-2. All series have unit root in levels at significance level of 5\% and 1\% except Housing and Commercial loans rate at significance level of $10 \%$ at ADF results. It can be said that results of ADF and PP test show that series are not stationary in levels at significance level of 5\% and $1 \%$. Therefore, first differenced variables are tested and reported Panel B in Table-2. Results of each unit root test show that all series are stationary at first difference.

Table 2: Unit Root Tests

\begin{tabular}{|c|c|c|c|c|c|c|c|}
\hline \multirow{3}{*}{\multicolumn{2}{|c|}{ Panel A }} & \multicolumn{3}{|c|}{ ADF } & \multicolumn{3}{|c|}{ PP } \\
\hline & & \multicolumn{3}{|c|}{ Test Statistic } & \multicolumn{3}{|c|}{ Test Statistic } \\
\hline & & None & $\mathbf{C}$ & C\&T & None & $\mathrm{C}$ & C\&T \\
\hline $\begin{array}{l}\text { Policy } \\
\text { Rate }\end{array}$ & $W F C_{\mathrm{t}}$ & 0.58 & -0.80 & -2.33 & 0.36 & -1.03 & -1.87 \\
\hline \multirow{4}{*}{$\begin{array}{l}\text { Retail } \\
\text { Rate } \\
\mathbf{R R}_{\mathbf{t}}\end{array}$} & Cash & 0.00 & -2.02 & -2.25 & -0.16 & -2.34 & -2.62 \\
\hline & Vehicle & -0.03 & -1.95 & -2.53 & -0.04 & -1.98 & -2.53 \\
\hline & Housing & -0.40 & $-2.79^{*}$ & $-3.23^{*}$ & -0.28 & -2.52 & -2.97 \\
\hline & Commercial & -0.37 & $-2.78^{*}$ & $-3.32^{*}$ & -0.04 & -2.39 & -2.97 \\
\hline \multirow{2}{*}{\multicolumn{2}{|c|}{ Panel B }} & \multirow{2}{*}{\multicolumn{3}{|c|}{$\begin{array}{l}\text { ADF } \\
\text { Test Statistic }\end{array}$}} & \multicolumn{3}{|l|}{$\mathbf{P P}$} \\
\hline & & & & & Test Stat & & \\
\hline $\begin{array}{l}\text { Policy } \\
\text { Rate } \\
\end{array}$ & $\Delta W F C_{\mathrm{t}}$ & $-6.80^{* * * *}$ & $-6.84^{* * *}$ & $-6.84^{* * *}$ & $-23.74^{* * *}$ & $-23.74^{* * *}$ & $-23.73^{* * *}$ \\
\hline \multirow{4}{*}{$\begin{array}{l}\text { Retail } \\
\text { Rate } \\
\Delta \mathbf{R R}_{\mathbf{t}}\end{array}$} & Cash & $-16.38^{* * *}$ & $-16.38^{* * *}$ & $-16.36^{* * *}$ & $-17.46^{* * *}$ & $-17.45^{* * *}$ & $-17.44^{* * * *}$ \\
\hline & Vehicle & $-6.10^{* * * *}$ & $-6.12^{* * *}$ & $-6.11^{\text {**** }}$ & $-24.78^{\text {**** }}$ & $-24.77^{\text {**** }}$ & $-24.75^{* * *}$ \\
\hline & Housing & $-9.18^{* * * *}$ & $-9.18^{* * *}$ & $-9.17^{* * *}$ & $-27.60^{* * * *}$ & $-27.59^{* * * *}$ & $-27.57^{* * * *}$ \\
\hline & Commercial & $-5.11^{* * *}$ & $-5.12^{* * *}$ & $-5.12^{* * *}$ & $-34.86^{* * *}$ & $-34.98^{* * *}$ & $-34.95^{* * *}$ \\
\hline
\end{tabular}

Three $\left(^{* * *}\right)$, two $\left(^{* *}\right)$ and one $\left(^{*}\right)$ asterisk indicate a level of significance at the $1 \%, 5 \%$ and $10 \%$ respectively.

After determining the variables are first order integrated, to obtain residuals Equation (1) is estimated with trend by OLS method. In order to determine the cointegration relationship between variables, Engle-Granger and threshold cointegration (TAR and M-TAR) tests are performed as the results are shown in Table-3.

In Table-3, there are two different estimates based on TAR and M-TAR models for each loan IRs. On the first of these, $\tau$ is zero and the threshold value determined according to the Chan (1993) approach in the other. The best models are selected jointly based on the AIC and SIC. The M-TAR models based on Chan (1993) approach are selected for cash, vehicle and housing loan IRs. However, the model that "Commercial" is dependent variable does not provide condition as $\rho_{1}<$ 0 . Therefore, the second-best model M-TAR with $\tau=0$ is selected for Commercial. 
Table 3: Cointegration Tests

\begin{tabular}{|c|c|c|c|c|c|c|c|c|c|c|}
\hline \multirow{3}{*}{\begin{tabular}{|c|} 
Retail Rate \\
Model \\
$\tau$ \\
\end{tabular}} & \multicolumn{5}{|l|}{ Cash } & \multicolumn{5}{|l|}{ Vehicle } \\
\hline & \multirow[t]{2}{*}{ EG } & \multicolumn{2}{|c|}{ TAR } & \multicolumn{2}{|c|}{ M-TAR } & \multirow[t]{2}{*}{ EG } & \multicolumn{2}{|c|}{ TAR } & \multicolumn{2}{|c|}{ M-TAR } \\
\hline & & 0 & 1.25 & 0 & 0.37 & & 0 & -1.52 & 0 & 0.45 \\
\hline$\rho$ & $\begin{array}{l}- \\
0.05^{* * *}\end{array}$ & & & & & $\begin{array}{l}- \\
0.10^{* * * *}\end{array}$ & & & & \\
\hline$\rho_{1}$ & & $-0.04^{* *}$ & $-0.04^{* *}$ & $-0.05^{* *}$ & $-0.09^{* * * *}$ & & $-0.08^{* * * *}$ & $-0.07^{* * * *}$ & $-0.13^{* * * *}$ & $-0.19^{* * * *}$ \\
\hline$\rho_{2}$ & & $-0.07^{* * * *}$ & $-0.07^{* * *}$ & $\begin{array}{l}- \\
0.06^{* * * *}\end{array}$ & $-0.04^{* * *}$ & & $-0.12^{* * * *}$ & $-0.16^{* * *}$ & $-0.07^{* * * *}$ & $-0.07^{* * *}$ \\
\hline Lag L. & 0 & 2 & 2 & 2 & 2 & 5 & 2 & 2 & 2 & 2 \\
\hline AIC & 2.11 & 2.13 & 2.13 & 2.13 & 2.12 & 2.32 & 2.38 & 2.38 & 2.38 & 2.37 \\
\hline SIC & 2.12 & 2.16 & 2.16 & 2.16 & 2.16 & 2.37 & 2.41 & 2.41 & 2.41 & 2.40 \\
\hline$\rho=0$ & $-4.01^{* *}$ & & & & & $-\overline{4.84^{* * * *}}$ & & & & \\
\hline $\begin{array}{l}\rho_{1}=\rho_{2} \\
=0\end{array}$ & & $7.84^{* * *}$ & $8.26^{* *}$ & $7.57^{* *}$ & $8.69^{* *}$ & & $11.69^{* * * *}$ & $13.52^{* * *}$ & $12.30^{* * *}$ & $14.88^{* * *}$ \\
\hline$\rho_{1}=\rho_{2}$ & & 0.72 & 1.54 & 0.19 & 2.38 & & 0.82 & $4.35^{* *}$ & 2.00 & $6.96^{* * *}$ \\
\hline Retail Rate & \multicolumn{5}{|l|}{ Housing } & \multicolumn{5}{|c|}{ Commercial } \\
\hline Model & EG & \multicolumn{2}{|c|}{ TAR } & \multicolumn{2}{|c|}{ M-TAR } & EG & \multicolumn{2}{|c|}{ TAR } & \multicolumn{2}{|c|}{ M-TAR } \\
\hline $\begin{array}{ll}\tau \\
\end{array}$ & & 0 & 1.22 & 0 & -0.27 & & 0 & 1.04 & 0 & 0.82 \\
\hline$\rho$ & $\overline{0}-08^{* * * *}$ & & & & & $\overline{0}-10^{* * * *}$ & & & & \\
\hline$\rho_{1}$ & & -0.03 & -0.03 & $-0.06^{* *}$ & $-0.04^{* *}$ & & $-0.06^{*}$ & $-0.05^{*}$ & -0.01 & $0.15^{* * *}$ \\
\hline$\rho_{2}$ & & $-0.13^{* * *}$ & $-0.16^{* * * *}$ & $\overline{0 .} 10^{* * * *}$ & $-0.19^{* * * *}$ & & $-0.12^{* * *}$ & $-0.13^{* * *}$ & $-0.18^{* * * *}$ & $-0.15^{* * *}$ \\
\hline Lag L. & 1 & 3 & 7 & 3 & 3 & 13 & 3 & 3 & 3 & 3 \\
\hline AIC & 2.39 & 2.37 & 2.36 & 2.38 & 2.36 & 2.87 & 2.97 & 2.97 & 2.95 & 2.91 \\
\hline SIC & 2.40 & 2.41 & 2.43 & 2.42 & 2.40 & 2.98 & 3.01 & 3.01 & 2.99 & 2.94 \\
\hline$\rho=0$ & $-4.33^{* *}$ & & & & & $-4.16^{* *}$ & & & & \\
\hline $\begin{array}{l}\rho_{1}=\rho_{2} \\
=0\end{array}$ & & $13.11^{* * *}$ & $18.24^{* * *}$ & $9.83^{* * * *}$ & $15.86^{* * *}$ & & $7.82^{* * * *}$ & $8.33^{* *}$ & $14.07^{* * *}$ & $26.75^{* * *}$ \\
\hline$\rho_{1}=\rho_{2}$ & 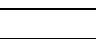 & $7.84^{* * * *}$ & $13.34^{* * *}$ & 1.49 & $13.15^{* * *}$ & & 2.104 & $3.11^{*}$ & $14.32^{* * * *}$ & $39.07^{* * *}$ \\
\hline
\end{tabular}

reached from Enders and Siklos (2001) for TAR and M-TAR and MacKinnon (1991) for EG.

When the results in Table- 3 were examined, the zero hypothesis $\left(\rho_{1}=\rho_{2}=\right.$ 0 ) indicating that there is no threshold cointegration was rejected in all selected models. Therefore, there is a threshold long-run equilibrium relationship between WFC and loan IRs. In addition, the zero hypothesis $\left(\rho_{1}=\rho_{2}\right)$, which emphasizes symmetrical adjustment of long-run deviations, has been rejected in all the selected models except cash. Thus, vehicle, housing and commercial loan IRs are asymmetrically adjusted against policy rate shocks. According to the analysis result of Vehicle IR, it is $\left|\rho_{1}\right|>\left|\rho_{2}\right|$. In other words, positive deviations (caused by WFC decline) are adjusted faster than negative deviations (caused by increases in WFC). So, there is a negative asymmetry in Vehicle IR. This is in favor of the consumer. However, the results of Housing and Commercial IRs were found to be $\left|\rho_{2}\right|>\left|\rho_{1}\right|$. Negative deviations (caused by WFC increase) are adjusted faster than positive deviations (caused by WFC decrease). This result is defined as positive asymmetry and is against the consumer. Lastly Cash IR is symmetrically adjusted $\left(\rho_{1}=\rho_{2}\right)$ and EG's procedure is valid for Cash IR. 
Table 4: Long-Run Coefficients

\begin{tabular}{|c|l|l|l|l|}
\hline Retail Rate & Cash & Vehicle & Housing & Commercial \\
\hline $\boldsymbol{\theta}$ & $9.33^{* * * *}$ & $6.16^{* * *}$ & $6.81^{* * *}$ & $6.34^{* * * *}$ \\
\hline $\boldsymbol{\phi}$ & $-0.01^{* * *}$ & $-0.00^{* * *}$ & $-0.00^{* * *}$ & $-0.00^{* * *}$ \\
\hline $\boldsymbol{\varphi}$ & $1.02^{* * * *}$ & $0.95^{* * *}$ & $0.74^{* * *}$ & $0.97^{* * *}$ \\
\hline
\end{tabular}

Three $\left({ }^{* * *}\right)$, two $\left({ }^{* *}\right)$ and one $\left(^{*}\right)$ asterisk indicate a level of significance at the $1 \%, 5 \%$ and $10 \%$ respectively. $\phi$ indicates that trend coefficient.

As shown in Table 4, long-run coefficients (based on Equation (1)) were obtained by the OLS method due to the fact that all loan IRs and WFC have a cointegration relationship. According to the long-run coefficients (Table 4), when there is a 100-basis point increase in WFC, the Vehicle and Commercial IR increases by approximately 95 and 97 basis points, respectively. The Housing IR, at a lower level than others, is affected by 74 basis points upward. The Cash IR, on the other hand, is the highest affected by the WFC and is expected to increase by about 102 basis points.

Table 5: Threshold Error Correction Models

\begin{tabular}{|c|l|l|l|l|}
\hline Retail Rate: & Cash & Vehicle & Housing & Commercial \\
\hline Model: & EG & M-TAR & M-TAR & M-TAR \\
\hline $\boldsymbol{\tau}$ & & 0.45 & -0.27 & 0 \\
\hline $\boldsymbol{\mu}$ & 0.01 & 0.01 & -0.00 & -0.02 \\
\hline $\boldsymbol{\delta}$ & $-0.04^{* * *}$ & & & \\
\hline $\boldsymbol{\delta}_{\mathbf{1}}$ & & $-0.12^{* * *}$ & $-0.03^{*}$ & 0.03 \\
\hline $\boldsymbol{\delta}_{\mathbf{2}}$ & & $-0.07^{* * *}$ & $-0.19^{* * *}$ & $-0.15^{* * *}$ \\
\hline $\boldsymbol{\alpha}_{\mathbf{1}}$ & $0.32^{* * *}$ & -0.04 & $-0.10^{* *}$ & $-0.49^{* * *}$ \\
\hline $\boldsymbol{\alpha}_{\mathbf{2}}$ & -0.03 & 0.02 & $0.22^{* * *}$ & $-0.19^{* * *}$ \\
\hline $\boldsymbol{\alpha}_{\mathbf{3}}$ & 0.06 & -0.04 & $0.14^{* * *}$ & \\
\hline $\boldsymbol{\alpha}_{\mathbf{4}}$ & $0.16^{* * *}$ & $0.23^{* * *}$ & & \\
\hline $\boldsymbol{\alpha}_{\mathbf{5}}$ & & $0.12^{* * *}$ & & $0.46^{* * *}$ \\
\hline $\boldsymbol{\beta}_{\mathbf{1}}$ & $0.24^{* * *}$ & $0.30^{* * *}$ & 0.02 & $0.43^{* * *}$ \\
\hline $\boldsymbol{\beta}_{\mathbf{2}}$ & & $0.09^{*}$ & $0.32^{* * *}$ & \\
\hline $\boldsymbol{\beta}_{\mathbf{3}}$ & & $0.24^{* * *}$ & & $23.38^{* * *}$ \\
\hline $\boldsymbol{\beta}_{\boldsymbol{i}}=\mathbf{0}_{\mathbf{1}} \boldsymbol{\delta}_{\mathbf{2}}$ & $26.79^{* * *}$ & $15.50^{* * *}$ & $15.02^{* * *}$ & $16.93^{* * * *}$ \\
\hline & 2.06 & $18.38^{* * *}$ & \\
\hline
\end{tabular}

Three $\left({ }^{* * *}\right)$, two $\left({ }^{* *}\right)$ and one $\left(^{*}\right)$ asterisk indicate a level of significance at the $1 \%, 5 \%$ and $10 \%$ respectively. $\delta$ is parameter in EG error-correction model.

Threshold error correction model estimation results based on M-TAR models are shown in Table 5. In addition to determining short-term relationships, the threshold error correction model also allows Granger causality testing. Threshold error correction terms $\left(\delta_{1}\right.$ ve $\left.\delta_{2}\right)$ are negative and statistically significant in all models except for positive deviation of Commercial IR. Therefore, it can be said that the commercial error correction mechanism does not work. Speed of adjustment to an increase in WFC is approximately 14-week for Vehicle, 5-week for Housing and 7 -week for Commercial loan rates. When there is a decrease in WFC, speed of adjustment is calculated as 8-week for Vehicle and 33-week for Housing loan rates. But Cash IR adjusts symmetrically against both increase and decrease in WFC and the speed of adjustment is approximately 25 weeks. However, an asymmetric adjustment for the Vehicle IR could not be determined in the short term. 
Our results reveal that there is not complete PT from policy IRs to retail lending rates for Turkey. Our results are in line with the results of Aydin (2007), Özdemir (2009), Yüksel and Özcan (2015) and Yıldırım (2014), Binici et.al. (2018) and Sahin and Cicek (2018) who found incomplete PT for Turkey. Hence, one can argue that there is significant mark-up effect in Turkish monetary market. Under the of Bertrand model, if there is no asymmetric information and market has competitive structure, price level must be equal to marginal cost. This argument implies that IPT is complete in competitive market structures.

In the threshold error correction model, the null hypothesis $\left(\beta_{i}=0\right)$ means that WFC is not Granger cause of loan IR. According to the test results, based on Enders and Siklos (2001), threshold Granger causality relationship from WFC to loan IRs are determined in all models.

\section{CONCLUSION}

In the current study, we analyzed the asymmetric adjustment process between official IR and RR (vehicle, housing, commercial and cash rates) by using TAR and M-TAR method and weekly data over the 2011-2021 period for Turkey. Because of the negative impacts of currency crises in August 2018 and Covid 19 Pandemia, monetary policy has become key tool to ensure stability in Turkish economy. Hence, to evaluate the effectiveness of monetary policy has gained importance than ever for the country.

The main findings of the current study can be summarized as following. The empirical results indicate that there is a long-run equilibrium relationship between $\mathrm{RR}$ and policy rate in Turkish banking market. In line with most of earlier empirical studies for Turkey, the estimated long-run and short run pass-through coefficients between the RRs (loan rates) and the official policy rates in our study show that the IPT is incomplete in Turkey, indicating the weakness of the IR channel in the monetary market. In other words, that complete PT (symmetry hypothesis) is clearly rejected for Turkey in the analyzed data period except. Not surprisingly, our empirical results provide evidence of significant mark-up of the retail loan rates. Since we found incomplete pass-through in transmission process, we can say that impact of central bank decision on macroeconomic variables (such as inflation, growth etc.) is accepted to be weak in Turkey.

M-TAR results show that while housing and commercial rates have positive asymmetry (rigid downward), vehicle IR has negative asymmetry which is in favor of consumer in Turkey. However, cash IR is symmetrically adjusted to policy rate changes. This means that housing and commercial rates react faster to policy rate when it is increasing rather than decreasing. The opposite, however, is true for vehicle rate. Moreover, our results highlight that increases in IRs will immediately affect the consumers through an increase in lending rates and consequent reduction in their purchasing power. Since discounts in official rates are not fully transmitted base rate declines would not have opposite effect of rising purchasing power to comparable extent. The speed of adjustment for an increase in the policy rate is 14- 
week for Vehicle, 5-week for Housing and 7-week for Commercial loan rates. On the contrary, speed of adjustment for a decrease in the policy rate is 8-week for Vehicle and 33-week for Housing loan rates. Only Cash IR adjusts symmetrically to increase or decrease in policy rate and the speed of adjustment is approximately 25 weeks. Additionally, in the threshold error correction model results show that threshold Granger causality relationship from policy rate to lending rates is determined for each.

Although the results of current study may be attributed to monopoly power, however there may be other reasons for IPT such as asymmetric information, menu costs, switching cost etc. Hence, further studies are needed to clarify the causes of asymmetric IPT in monetary market to ensure macroeconomic stability in Turkey.

\section{REFERENCES}

Abbasoğlu D.F., Aysan A.F. \& Gunes A., (2007). Concentration, Competition, efficiency and profitability of Turkish banking sector in the post-crises period. Munich Personel RePEC Archieve, MPRA Paper No:5494.

Aksoy T. (2019). "Concentration in Turkish Banking Sector" in Researches in Economics \& Finance, pp.111-116 (Ed. Hilal Y1ld1z, Ahmet Sedat Aybar, IJOPEC Publication, London.

Apergis N. \& Cooray A. (2015). Asymmetric interest rate pass-through in the U.S., the U.K and Australia: New evidence from selected individual banks. Journal of Macroeconomics, 45, 155-172.

Avci S.B. \& Yucel E. (2017). Effectiveness of monetary policy:evidence from Turkey. Euroasian Economic Review, 7, 179-213.

Aydin H.I. (2007). Interest rate pass-through in Turkey. Research and Monetary Policy Department. Working Paper No:07/05, The Central Bank of Republic of Turkey (TCMB).

Aziakpono M.J. \& Wilson M.K., (2013). Interest rate pass-through and monetary policy regimes in South Africa.

Becker R., Osborn D.R. \& Yildirim D., (2012). A threshold cointegration analysis of interest rate pass-through to UK mortgage rates. Economic Modelling, 29, 2504-2513.

Bennouna H., (2019). Interest rate pass-through in Morocco:Evidence from bank-level survey data. Economic Modelling, 80, 142-157.

Binici M., Kara H. \& Özlü P. (2016). Faiz Koridoru ve Banka Faizleri: Parasal Aktarım Mekanizmasına Dair Bazı Bulgular. TCMB Çalışma Tebliği, 16/08.

Binici M., Kara H. \& Özlü P. (2018). Monetary transmission with multiple policy rates: evidence from Turkey. Applied Economics, 51(17), 1869-1873. 
Borenstein S., Colin C. \& Richard G. (1997). Do gasoline prices respond asymmetrically to crude oil price changes? Quarterly Journal of Economics, 112, 305-339.

Borio C.E.V. \& Fritz W. (1995). The response of short-term bank lending rates to policy rates: A Cross-country perspective. BIS Working Paper, No:27.

Büberkökü Ö. \& Kızılder C. (2019). Geleneksel olmayan para politikası uygulamaları döneminde faiz oranı geçişkenliğinin incelenmesi. Van Yüzüncü $Y_{l} l$ Üniversitesi İktisadi ve İdari Bilimler Fakültesi Dergisi, Bahar/8.

Cecchin I. (2011). Mortgage rate pass-through in Switzerland. Working Papers 2011-08, Swiss National Bank.

Chan, Kung-Sik. (1993). Consistency and Limiting Distribution of the Least Squares Estimator of a Threshold Autoregressive Model. The Annals of Statistics 21: $520-33$

Chong B.S., Liu M-H. \& Shrestha K. (2006). Monetary transmission via the administered interest rates channel. Journal of Banking \& Finance, 30, 1467-1484.

Contuk F.Y. \& Burucu H., (2016). Concentration and Competition in banking sector: Turkey case (2001-2015). Uluslararası Sosyal Araştırmalar Dergisi, 9(46), 884-892.

Cottarelli C. \& Kourelis A., (1994). Financial structure, bank lending rates, and the transmission mechanism of monetary policy. IMF Staff Papers, 41(4), 587623.

Corvoisier S. \& Gropp R.E., (2001). Bank concentration and retail rates. Journal of Banking\& Finance, 26(11), 2155-2189.

Dickey, D. A. \& Fuller, W. A. (1979). Distribution of the estimators for autoregressive time series with a unit root. Journal of the American Statistical Association, 74(366a), 427-431.

Ekinci R., Ceylan F, Tüzün O. \& Kahyaoğlu H. (2016). TCMB Ağırlıklı Ortalama Fonlama Maliyeti'nin BİST100 Üzerindeki Etkisi. Journal of Yaşar University, 11(44), 263-277.

Enders, W. \& Granger, C. W. J. (1998). Unit-root tests and asymmetric adjustment with an example using the term structure of interest rates. Journal of Business \& Economic Statistics, 16(3), 304-311.

Enders, W. \& Siklos, P. L. (2001). Cointegration and threshold adjustment. Journal of Business \& Economic Statistics, 19(2), 166-176.

Engle, R. F. \& Granger, C. W. (1987). Co-integration and error correction: representation, estimation, and testing. Econometrica: Journal of the Econometric Society, 251-276. 
Gambacorta L. \& Iannotti S., (2007). Are there asymmetries in the response of bank interest rates to monetary shocks? Applied Economics, 39(19), 2503-2517.

Granger C.W.J. \& Newbold P. (1974). Spirous regressions in econometrics, Journal of Econometrics, 2(2), 111-120.

Günalp B. \& Çelik T., (2006). Competition in the Turkish banking industry. Applied Economics, 38(11), 1335-1342.

Hoffman B. \& Mizen P. (2004). Interest rate pass through and monetary transmission: Evidence from individual financial institutions' retail rates, Economics, 71, 99-123

Hannan T.H. \& Berger A.N., (1991). The rigidity of prices:Evidence from banking industry. The American Economic Review, 81(4), 938-948.

Hofmann B. \& Mizen P., (2004). Interest rate pass-through and monetary transmission:Evidence from individual financial institutions' retail rates. Economica, 71, 99-123.

Haughton, A.Y. \& E. M. Iglesias (2012). Interest rate volatility, asymmetric interest rates pass through and the monetary transmission mechanism in the Caribbean compared to US and Asia. Economic Modeling 29, 2071-2080.

Jamilov R. \& Egert B. (2014). Interest rate pass-through and monetary policy asymmetry: A journey into Caucasian Black Box, Journal of Asian Economics, 31, 57-70.

Kara H. (2015). Faiz Koridoru ve Para Politikası Duruşu. TCMB Ekonomi Notlarl, 2015-13.

Karagiannis S., Panagopoulos Y. \& Vlamis P. (2010). Symmetric or asymmetric Interest rate adjustment? Evidence from Greece, Bulagria and Slovenia. The Hellenic Observatory, GreeSE Paper no:39.

Kasman A. (2002). Cost efficiency, scale economies, and technological progress in Turkish banking. Central Bank Review, 2(1), 1-20.

Kasman S. \& Kasman A., (2015). Bank competition, concentration and financial stability in the Turkish banking industry. Economic Systems, 39, 502-517.

Kuzu S. (2017). Türkiye Cumhuriyeti Merkez Bankas1 (TCMB) Faiz Koridoru Stratejisinin Hisse Senedi Piyasası ve Döviz Kuru Üzerine Etkisinin Analiz Edilmesi. Uygulamalı Sosyal Bilimler Dergisi, 1(2), 46-61.

Lim G.C. (2002). Bank interest-rate adjustments: Are they symmetric? Economic Record, 77(237): 135-147.

Liu M-H., Margoritis D. \& Tourani-Rad A., (2008). Monetary policy transparancy and pass-through of retail rates. Journal of Banking \& Finance, 32, 501-511. 
MacKinnon, J. (1991) Critical values for cointegration tests. In: Engle, R. and Granger, C., Eds., Long Run Economic Relationships, Oxford University Press, Oxford, 267-276.

Malile I. (2013). Asymmetry of interest rate pass through in Albenia. Academic Journal of Interdisciplinary Studies, 2(9), 539-543.

Marotta G. (2009). Structural breaks in the lending interest rate pass-through and the euro. Economic Modelling, 26:191-205.

Matemilola B.T., Bany-Ariffin A.N. \& Muhtar F.E. (2015). The impact of monetary policy on bank lending rate in South Africa. Borsa Istanbul Review, 15(1), 53-59.

Maudos J. \& de Guevara F.J., (2004). Factors explaining the interest margin in the banking sectors of the European Union. Journal of Banking \& Finance, 28(9), 2259-2281.

Mercan M. \& Yolalan R. (2000). Türk bankacılık sisteminde ölçek ve mülkiyet yapıları ile finansal performans ilişkisi. IMKB Dergisi, 4(15), 1-26.

Neumark D. \& Sharpe S. (1992). Market structure and the natüre of price rigidity:Evidence from the market for consumer deposits. Quarterly Journal of Economics, 107(2), 657-680.

Özdemir B.K. (2009). Retail bank interest rate pass-through:the Turkish Experience. International Research Journal of Finance and Economics, 28, 7-15.

Panzar J. C., \& Rosse J. N. (1987). Testing for 'monopoly' equilibrium. Journal of Industrial Economics, 25, pp. 443-456.

Payne J.E. (2007). Interest rate pass-through and asymmetries in adjustable rate mortgages. Applied Financial Economies, 17(7), 1369-1376.

Phillips, P. C. (1986). Understanding spurious regressions in econometrics. Journal of econometrics, 33(3), 311-340.

Phillips, P. C. \& Perron, P. (1988). Testing for a unit root in time series regression. Biometrika, 75(2), 335-346.

Quoc B.N.K. \& Huy N.N.H. (2013). Emprical evidence of asymmetric interest rate pass-through in Vietnam. Journal of Asian Business and Economic Studies, 218, 79-93.

Repková I. \& Stavárek D. (2014). Concentration and Competition in the banking sector of Turkey, Economic Interferences, XVI (36), 625-640.

Rocha M.D. (2012). Interest rate pass-through in Portugal: Interactions, asymmetries and heterogeneities. Journal of Policy Modeling, 34, 64-80.

Roelands S. (2012). Asymmetric interest rate pass-through from monetary policy:the role of bank regulation. 
Rutayisire M.J. (2020). Modelling interest rate pass-through in Rwanda:Are the interest rate adjustment dynamics symmetric or asymmetric? African Economic Research Consortium, No:402.

Sahin S. \& Cicek S. (2018). Interest rate pass-through in Turkey during the period of unconditional interest rate pass-through. Quantitative Finance and Economics, 2(4), 837-859.

Sander H. \& Kleimer S. (2004a). Convergence in Euro-zone retail banking? What interest rate pass-through tells us about monetary policy transmission, competion. Journal of International Money and Finance, 23, 461-492.

Sander H. \& Kleimer S. (2004b). Interest rate pass-through in a enlarged Europe:The role of banking market structure for monetary policy transmisson in transition countries, Research Memorandum 044, Maastricht University, Maastricht Research School of Economics and Technology and Organization (METEOR).

Scholnick B. (1999). Interest rate asymmetries in long-term loan deposit markets. Journal of Financial Services Research, 16(1), 5-26.

Scholnick B. (1996). Asymmetric Adjustment of commercial bank interest rates:Evidence from Malaysia and Singapore. Journal of International Money and Finance, 15(3), 485-496.

Sørensen C.K. \& Werner T. (2006). Bank Interest rate pass-through in the Euro area: A cross country comparison, European Central Bank, Woking Paper, No:580.

Stigliz J.E. \& Weiss A. (1981). Credit rationing in markets with imperfect information. The American Economic Review, 71(3), 393-410.

Su C-W. \& Chang H-L. (2010). Asymmetric adjustment in the lending deposit rate spread:Evidence from Eastern European countries. Romanian Journal of Economic Forecasting 2, 165-175.

Sznajderska A. (2012), On the emprical evidence of asymmetry effects in the interest rate pass-through in Poland, National Bank of Poland, Working Paper, No:114.

TBB, (2021). Banks in Turkey, The Banks Association of Turkey (TBB), https://www.tbb.org.tr/modules/banka-bilgileri/banka_sube_bilgileri.asp (Erişim Tarihi: 24.08.2021).

TCA, (2013). Turkish Competition Authority (TCA), Decision No:1313/198-100, Decision date:08.03.2013, https://www.rekabet.gov.tr/Karar?kararId=30851aa5-2cf3-4c54-b284e192ed6ed71b (Erişim Tarihi: 05.01.2021). 
Valadkhani A. \& Anwar S. (2012). Interest rate pass-through and asymmetric relationship between the cash rate and mortgage rate, Economic Record, 88(282), 341-350.

Van Leuvensteijn M., SӨrensen C.K., Bikker J.A. \& von Rixtel A.R.J.M., (2007). Impact of bank competiton on the interest rate pass-through in the Euro Area, European Central Bank, Working Paper Series, No:768.

Winker P., (1999) Sluggish adjustment of interest rates and credit rationing: an application of unit root testing and error correction modelling, Applied Economics, 31:3, 267-277.

Wang K-M. \& Lee Y-M. (2009). Market volatility and retail interest rate pass-through. Economic Modelling, 26, 1270-1282.

Wang K-M. \& Thi T-B-N. (2008). Asymmetric pass-through and risk of interest rate:An ampirical exploration of Taiwan and Hong-Kong.

Yildırım D. (2014). Asymmetric interest rate pass-through to Turkish loan rates, İktisat, İşletme, Finans, 29(334), 09-28.

Yüksel E. \& Özcan K.M. (2015). Interest rate pass-through in Turkey and impact of the global financial crisis:asymmetric threshold cointegration analysis. Journal of Business Economics and Management, 14(1), 98-113.

Zaim, O. (1995) The effects of financial liberalization on the efficiency of Turkish commercial banks, Applied Financial Economics, 5, 257-64.

Zhang Z., Tsai S-L. \& Chang T. (2017) New Evidence of Interest Rate Passthrough in Taiwan: A Nonlinear Autoregressive Distributed Lag Model, Global Economic Review, 46:2, 129-142. 